\title{
HEDONIC PRICING MODEL FOR THE ECONOMIC VALUATION OF CONSERVATION LAND IN MEXICO CITY
}

\author{
ESTEBANIA TEYELIZ MARTÍNEZ-JIMÉNEZ ${ }^{1}$, ENRIQUE PÉREZ-CAMPUZANO² \\ $\&$ ALONSO AGUILAR IBARRA ${ }^{3}$ \\ ${ }^{1}$ National Autonomous University of Mexico (UNAM), Mexico \\ ${ }^{2}$ Instituto de Geografía, (UNAM), Mexico \\ ${ }^{3}$ Instituto de Investigaciones Económicas, (UNAM), Mexico
}

\begin{abstract}
Urban sprawl is a worldwide tendency that affects agricultural production land, forests, and areas of environmental value in peri-urban areas. A hedonic pricing model, specified with GIS measures, was applied for a sample of plots for sale in the conservation land (CL) of Mexico City. It was used for determining the value of the urban fringe land and for estimating the impact of both infrastructure and amenities on price per square meter. Physical and locational characteristics of rural land were considered, such as price per square meter of land, supply of public services (water, electricity, sewage), distance to infrastructure and distance to a natural area. Results indicate that the specification performed well across two functional forms (semi-log and $\log -\log$ ). The model showed that proximity to a natural area has positive influence, nevertheless the sewage system is the main feature that determines a higher price. Analyses of land prices in the rural-urban fringe can help in decision-making and policies regarding environmental conservation.
\end{abstract}

Keywords: hedonic pricing, peri-urban, environmental valuation, land values, conservation land, Mexico City.

\section{INTRODUCTION}

Cities have multiplied and expanded rapidly worldwide over the past two centuries, so they have increased pressures on the world's ecosystems [1]. According to UNFPA [2], in developing countries, cities of 100,000 or more inhabitants are expected to triple their built-up land area to $600,000 \mathrm{~km}^{2}$ in the first three decades of this century. This situation is especially severe in fast urbanizing and industrializing developing countries, such as China and Mexico [3]. Hence, urbanization and city expansion threaten the provision of ecosystem services that are supplied by the periphery.

Rural land, forests and farmland in both the urban and peri-urban areas provide multiple ecosystem services (e.g., biodiversity, climate regulation, rural culture, aesthetic and recreational services and open space), as well as characteristics that impact agricultural production [4]. Thus, these green areas are commonly regarded as a remedy to the urban environmental problems [5]. However, urban sprawl is explicitly affecting peri-urban areas, because they provide land for current and future real-estate developments, so these plots are disputed by diverse sectors, such as agricultural production, ecological preservation, or residential development [4].

Economic valuation of ecosystems has been used since the 1960s, but this kind of studies strongly increased in the 1990s as they provided information on the economic importance of ecosystem services, or the costs derived from their loss, which proved useful for decision-making [6]. It is based on the intensity of changes in people's preferences under small or marginal changes in the quantity or quality of environmental goods or services [7]. There are two broad methodological approaches for estimating economic values of market and nonmarket goods and services: stated preferences and revealed preferences [8]. The latter 
category includes the hedonic pricing method, which implies that the economic value of land is influenced by adjacent natural assets.

\subsection{Background}

The literature examined for the case of Mexico City, reveals few studies on environmental valuation. Almeida-Leñero et al. [9], studied the importance of the Magdalena River Basin. Martínez-Rivera [10], made an economic valuation of the environmental services of agriculture, the recharge of the aquifer and carbon sequestration of the natural areas surrounding Mexico City, labelled as the "conservation land" perimeter (CL). ArreguínSámano and Torres-Pérez [11], examined the water ecosystem service of the Magdalena Contreras area. Another valuation study was carried out in the urban wetlands of Mexico City [12] and Martínez-Jiménez's [13] work focused on the economic valuation of hydrological environmental services of the CL, specifically in the mountains in southern Mexico City.

Hedonic pricing models carried out in Mexico City are scarce. In fact, Sobrino [14] conducted a study on housing prices and submarkets in the city, however, this author highlights the lack of information on urban housing prices. Lara et al. [15], used a hedonic pricing model in order to estimate the costs of urban sprawl in the Mexico City metropolitan area. Another example is the study of Chakraborti et al. [16], who analysed the variation in air pollution levels with respect to the values of buildings within the city.

In this sense, this article aims to provide an economic valuation of the Conservation Land in Mexico City by using a hedonic pricing model (HPM). It was estimated for determining which attributes are relevant for plot values in the peri-urban area.

\section{THEORY OF HEDONIC PRICING VALUATION}

A comprehensive explanation of the history and theory of hedonic pricing is given by Freeman et al. [17]. It was Rosen [18], the first to postulate that houses, or similar heterogeneous products, are not homogeneous and have different characteristics, who defined hedonic prices as the implicit prices of attributes revealed from observed prices of differentiated products. The hedonic pricing models (HPM), including the variables delimited by the geographical information systems (GIS), allow to infer the impact of attributes on the values of a property (e.g., houses or parcels) [19]. For example, one cannot purchase a view of a lake on its own, but must purchase property that provides a lake view as well as other amenities and disamenities associated with the property [20].

Applications of HPM have been used to estimate different land value attributes. Geoghegan et al. [21], incorporated GIS to analyze the pattern of surrounding land uses, which affect land values in Washington, USA. Shonkwiler and Reynolds [22], determined non-agricultural uses of the land, located at the urban fringe. Bastian et al. [19], measured recreational and scenic amenities associated with rural land. The literature reviewed reveals natural or environmental amenities [23], [24], as factors contributing to land values. For example, Tyrväinen [25] studied how urban forest benefits are capitalized in property prices in Finland [26]; grassland in France [27], landscapes also in France [28]. Hence, it is important to note that hedonic pricing is often used to value urban green space [29] and open space [8], [30].

\section{METHODS}

\subsection{Study area}

Mexico City has a population of about 8.9 million inhabitants [31]. According to the Land Management Program of Mexico City [32], its surface comprises urban areas (about 60.9 
thousand ha (41\%) and conservation land (about 873 thousand ha (59\%), distributed in nine city municipalities: Cuajimalpa de Morelos (7.5\%), Álvaro Obregón (3.1\%), La Magdalena Contreras (5.9\%), Tlalpan (2.4\%), Xochimilco (11.9\%), Tláhuac (7.2\%), Milpa Alta (32.2\%), Gustavo A. Madero (1.4\%) and Iztapalapa (1.4\%) (Fig. 1).

The Conservation Land (CL) decree was set up in 1978, when the Master Plan for Urban Development of Mexico City, divided the territory into "urbanized sectors, territorial reserves and land dedicated to conservation, recognized as essential (with strong restrictions on land use), in order to maintain the ecological balance of the city" [33], [34].

The CL provides many ecosystem services (ES), such as: aquifer recharge (about 60-70\% of available water comes from aquifers); climate regulation; carbon-sequestration and biodiversity preservation functions. It also provides opportunities for recreation, aesthetic and cultural values, as well as production of food and raw materials [35].

Nevertheless, this land has been under several sources of pressure, resulting in a decreased capacity for supplying ecosystem services [33]. For example, urban expansion, from 2003 to 2007 , covered 5.3 thousand ha of CL, which is, approximately 1.3 thousand ha per year [36]. Urbanization is characterized by three forms: (1) expansion of traditional towns; (2) poor and illegal settlements; and (3) land occupations by middle classes [37].

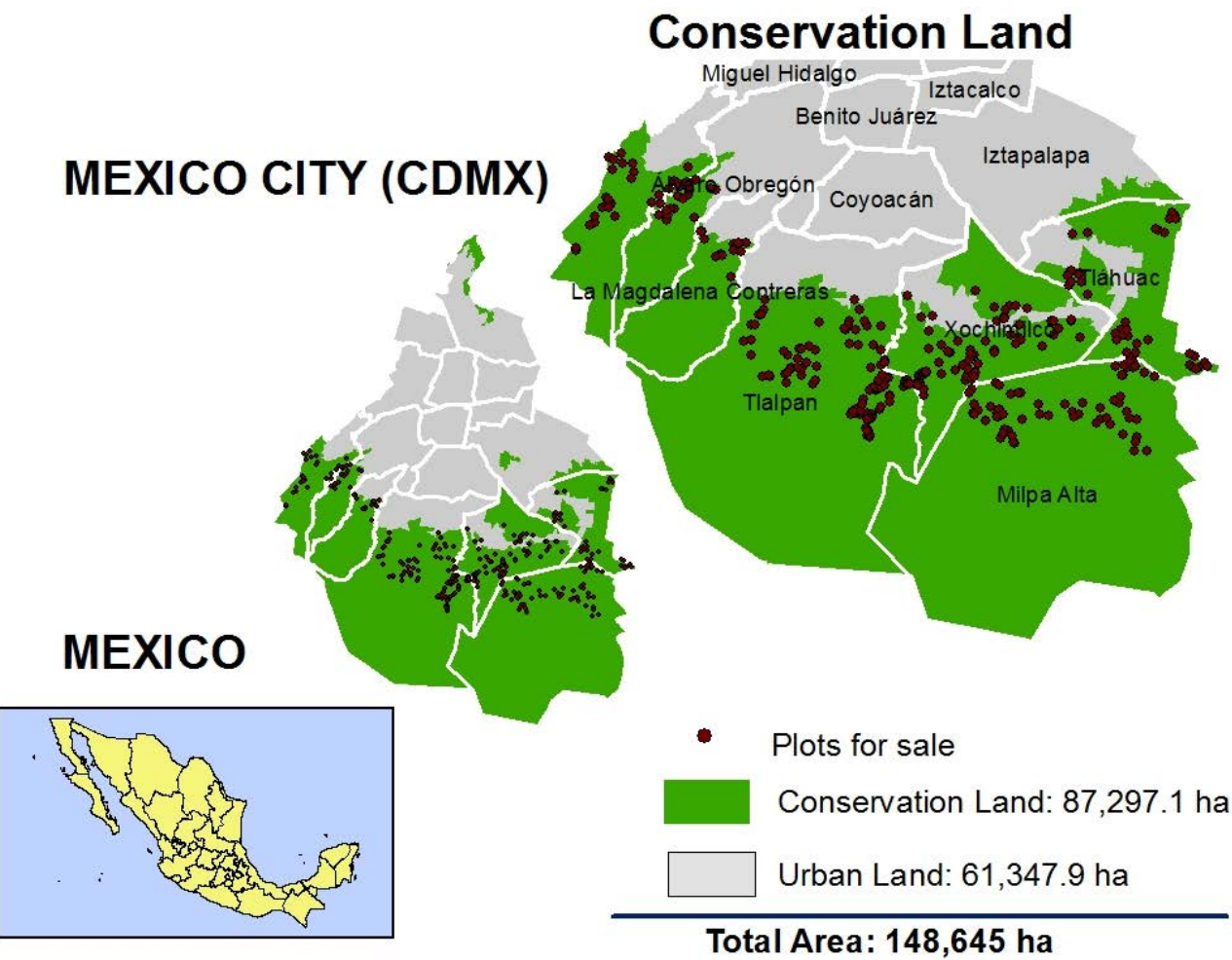

Figure 1: Map of Conservation land in Mexico City showing the sampled plots for sale used in our analysis. (Source: prepared by the authors by using data from INEGI (2010) and PAOT-SEDEMA (2012).) 
Another element of pressure is the land use change, which occurs because agricultural income is rather low in comparison to urban income. Therefore, land owners get a greater profit by selling it, rather than engaging in agricultural or forestry activities, which provide a lower income [34].

Despite the ban on the establishment of urban construction in the CL, the expansion of irregular settlements continues to grow, and the real-estate market remains, increasing the environmental deterioration of the entire area. Thus, keeping conservation land as a natural reserve has proven extremely difficult due to urban expansion, both legal and illegal.

\subsubsection{The survey}

The analysis was conducted for the CL, where developable parcels/plots (e.g., mainly pasture and forest areas) with environmental benefits are being rapidly converted to residential use. In order to estimate the hedonic pricing eqn, fieldwork was carried out from March to August 2016. Data was collected in two ways. One consisted in searching data on real-state websites (www.metroscubicos.com; www.inmuebles24.com), and the other was to map several routes and look for plots for sale banners by foot. The "mystery shopper technique" [38], was used, although this practice is commonly applied in service organizations to measure intangible service experiences. In this case, we act as if we were buyers to get real information on sale prices. The survey provided information for 348 plots for sale located on the CL as shown in Fig. 1.

\subsection{Data}

Three types of explanatory variables were used: attributes, location and environmental features. The plot attribute's set included plot size and urban services, as electricity, sewage and water service. The second group of variables refers to the location characteristics of the plots, such as proximity to marketplaces, rural communities, highways and roads. Finally, the environmental set relates to the distance to a natural protected area or woodland, and whether the parcel is sloped, which is a feature that determines its suitability for construction. Distances were estimated with a geographic information system (GIS) in which each variable represents the lineal distance from the plot $i$ to the nearest point of each category. The variables used in estimating the HPM are summarized in Table 1.

\subsection{Econometric model}

We used the typical hedonic pricing equation:

$$
P i=\mathrm{Xib}+\varepsilon \mathrm{i}
$$

where $\mathrm{Pi}$ is the price of plot $\mathrm{i}, \mathrm{Xi}$ the matrix of explanatory variables (including an intercept), $\mathrm{b}$ the vector of parameters to be evaluated, and $\varepsilon i$ an error term [28].

The explanatory variables comprise three sets of characteristics: 1) variables that describe urban services, 2) characteristics of the area, and 3) environmental attributes.

The dependent variable (in this case price of plot per square meter - Priceplot) is statistically disaggregated into marginal implicit prices for each explanatory attribute. Linear and logarithmic functional forms were used, with a semi-log and double log specification as the best fit. The semi-log equation estimated was:

$$
\begin{gathered}
\ln \text { Priceplot }=\beta 1+\beta 2 \text { Water }+\beta 3 \text { Sewage }+\beta 4 \text { Electricty }+\beta 5 \text { Market }+ \\
\beta 6 \text { Ruralcom }+\beta 7 \text { Via }+\beta 8 \text { Carr }+\beta 9 A N P+\beta 10 \text { BOS }+\beta 11 \text { Slope } 1+\beta 12 \text { Slope } 2 .
\end{gathered}
$$


Table 1: Variables description and expected sign of coefficient. (Source: prepared by the authors.)

\begin{tabular}{|l|c|l|}
\hline \multirow{2}{|c|}{ Name } & \multicolumn{2}{|c|}{ Variables } \\
\cline { 2 - 3 } & $\begin{array}{c}\text { Expected } \\
\text { sign }\end{array}$ & \multicolumn{1}{c|}{$\begin{array}{c}\text { Description } \\
\text { (units of measure) }\end{array}$} \\
\hline Priceplot & Dependent & Price per square meter of land in Mexican pesos. \\
\hline Water & + & $\begin{array}{l}\text { Dummy variable: 1 if the plot has water service, 0 } \\
\text { otherwise. }\end{array}$ \\
\hline Sewage & + & Dummy variable: 1 if there is sewage, 0 otherwise. \\
\hline Electricity & + & $\begin{array}{l}\text { Dummy variable: 1 if the plot has electricity, 0 } \\
\text { otherwise. }\end{array}$ \\
\hline Market & - & Distance to nearest marketplace in meters. \\
\hline Ruralcom & - & Distance to nearest rural community in meters. \\
\hline Via & - & Distance to nearest road in meters. \\
\hline Carr & - & Distance to nearest highway in meters. \\
\hline ANP & - & Distance to nearest natural protected area in meters. \\
\hline BOS & - & Distance to nearest woodland in meters \\
\hline Slope1 & - & $\begin{array}{l}\text { Dummy variable: } 1 \text { if the property is sloped and it is no } \\
\text { appropriate for construction, 0 otherwise. }\end{array}$ \\
\hline Slope2 & - & $\begin{array}{l}\text { Dummy variable: } 1 \text { if the property is semi sloped and it } \\
\text { is not appropriate for construction, 0 otherwise. }\end{array}$ \\
\hline
\end{tabular}

For the double log model, the natural log was used for all continuous variables, the equation was:

$$
\begin{gathered}
\ln \text { Priceplot }=\beta 1+\beta 2 \text { Water }+\beta 3 \text { Sewage }+\beta 4 \text { Electricty }+\beta 5 \text { lnMarket }+ \\
\beta 6 \ln \text { Ruralcom }+\beta 7 \operatorname{lnVia}+\beta 8 \ln \text { Carr }+\beta 9 \ln A N P+\beta 10 \ln B 0 S+ \\
\beta 11 \text { Slope } 1+\beta 12 \text { Slope } 2 .
\end{gathered}
$$

\section{RESULTS}

\subsection{Descriptive statistics}

We used price per square meter rather than total sale price, to standardize the prices because land parcels considerably varied in size. The average sale price is \$2054.5 (112.9 usd; the average exchange rate from March to August 2016 was 18.2 Mexican pesos per US dollar), with a minimum of $\$ 400$ (22 usd) to $\$ 8500$ Mexican pesos (467 usd) per square meter, and a standard deviation of $\$ 1351.6$ pesos ( 74.3 usd). The average plot size is about 1800 square meters, with a minimum of 80 to 100000 square meters. The parcel size variable was excluded because its coefficient was insignificant. Descriptive statistics of variables are presented in Table 2 .

\subsection{Econometric results}

The hedonic models were specified and estimated by ordinary least squares (OLS). Several diagnostics were performed to improve the accuracy of estimates. The Jarque-Bera test was conducted, and showed data have the skewness and kurtosis matching a normal distribution. 
The White's test for heteroskedasticity, failed to reject the null hypothesis of homoscedasticity, so residuals are homoscedastic.

Multicollinearity, after the Theil index and Variance Inflation Factor, was not found as a problem. It has to be noted, however, that the correlation matrix showed correlation between some urban services variables, due to the fact that these might be complementary. Water and sewage $(0.61)$ and water and electricity $(0.63)$ presented the highest correlation. Since the Durbin-Watson test was inconclusive (i.e. values were in the undefinition zone), we decided, nevertheless, to include these variables in the analysis.

The results of each model (semi-log and double-log, for both dependent variable is the natural $\log$ ) are shown in Table 3. Both models have a low adjusted R squared statistic: 0.27 and 0.28 , respectively. Seven out of 12 estimated coefficients $(58 \%)$ were statistically significant at the $10 \%$ level in the semi-log model. With respect to the double-log model eight out of 12 estimated coefficients $(67 \%)$ were statistically significant at the $5 \%$ level. This indicates that the double-log model had a better fit. As expected, the estimated coefficients of the plot attribute's set were positive, but only sewage was found statistically significant. Signs for the other variables were identical between the two functional forms, except for marketplace variable, which has a negative sign in the semi-log model, however it was not statistically significant. For the double-log model, the estimated coefficients represent elasticities: the percent change in the dependent variable given a percent change in an independent variable [21]. In other words, a $10 \%$ increase in distance to a highway leads to a $0.5 \%$ decrease of the plot selling price.

\section{DISCUSSION AND CONCLUSION}

Even though the coefficients were significant, both models presented rather low R-squared values: 0.27 and 0.28 for the semi- and double-log models, respectively. The fact that the constant term in both models was highly significant $(\mathrm{p}<0.01)$ means that unobserved variables also explain the dependent variable [39]. Indeed, hedonic pricing modelling sometimes involves low R-squared values which nevertheless, fits the data and also generates reasonable results (e.g. [8], [40]). This might be the expression of very specific features that change according to the local context, which are difficult to measure and include in econometric analyses of hedonic pricing. Geoghegan et al. [21], discuss ways to improve estimates for this method.

Table 2: Descriptive Statistics of the sampled plots for sale in the conservation land of Mexico City. (Source: prepared by the authors.)

\begin{tabular}{|l|l|l|l|l|l|}
\hline \multirow{2}{*}{ Variable name } & \multicolumn{5}{|l|}{ Descriptive statistics } \\
\cline { 2 - 6 } & Mean & SD & Max & Min & Units \\
\hline Priceplot & 2054.5 & 1351.6 & 8500 & 400.0 & \$ pesos \\
\hline Water & 0.44 & 0.50 & 1.0 & 0.0 & Dummy \\
\hline Sewage & 0.32 & 0.47 & 1.0 & 0.0 & Dummy \\
\hline Electricity & 0.63 & 0.48 & 1.0 & 0.0 & Meters \\
\hline Market & 3151.7 & 2550.3 & 11293 & 197.0 & Meters \\
\hline Ruralcom & 633.1 & 502.7 & 3388.8 & 8.9 & Meters \\
\hline Via & 429.9 & 567.2 & 3441.4 & 0.3 & Meters \\
\hline Carr & 1508.1 & 2075.1 & 11557 & 0.1 & Meters \\
\hline ANP & 3275.4 & 2153.4 & 9603.9 & 1.0 & Meters \\
\hline BOS & 984.1 & 1313.7 & 6221.3 & 1.00 & Meters \\
\hline Slope1 & 0.09 & 0.29 & 1.00 & 0.00 & Dummy \\
\hline Slope2 & 0.66 & 0.47 & 1.00 & 0.00 & Dummy \\
\hline
\end{tabular}


Table 3: Hedonic regression results for semi-log and double-log models.

\begin{tabular}{|c|c|c|}
\hline \multirow[t]{2}{*}{ Variable name } & Semi-log model & Double-log \\
\hline & $\begin{array}{l}\text { Coefficient } \\
\text { (t-statistics) }\end{array}$ & $\begin{array}{l}\text { Coefficient } \\
\text { (t-statistics) }\end{array}$ \\
\hline Constant & $\begin{array}{l}7.61 * * * \\
(50.55)\end{array}$ & $\begin{array}{l}6.68 * * * \\
(15.33) \\
\end{array}$ \\
\hline Water & $\begin{array}{l}0.03 \\
(0.37) \\
\end{array}$ & $\begin{array}{l}0.08 \\
(1.06) \\
\end{array}$ \\
\hline Sewage & $\begin{array}{l}0.21 * * * \\
(2.92)\end{array}$ & $\begin{array}{l}0.20^{* * * *} \\
(2.80)\end{array}$ \\
\hline Electricity & $\begin{array}{l}0.08 \\
(1.06) \\
\end{array}$ & $\begin{array}{l}0.04 \\
(0.62)\end{array}$ \\
\hline Market & $\begin{array}{l}-9.96 \mathrm{E}-06 \\
(-0.70)\end{array}$ & $\begin{array}{l}0.09 * * \\
(2.59)\end{array}$ \\
\hline Ruralcom & $\begin{array}{l}2.77 \mathrm{E}-04 * * * \\
(4.84)\end{array}$ & $\begin{array}{l}0.16^{* * * *} \\
(4.76) \\
\end{array}$ \\
\hline Via & $\begin{array}{l}-9.42 \mathrm{E}-05^{*} \\
(-1.84)\end{array}$ & $\begin{array}{l}-0.05^{* *} \\
(-2.42) \\
\end{array}$ \\
\hline Carr & $\begin{array}{l}-3.07 \mathrm{E}-05 \\
(-1.61)\end{array}$ & $\begin{array}{l}-0.05 * * * \\
(-2.80)\end{array}$ \\
\hline ANP & $\begin{array}{l}-5.63 \mathrm{E}-05 * * * \\
(-3.04)\end{array}$ & $\begin{array}{l}-0.04^{* *} \\
(-2.35) \\
\end{array}$ \\
\hline BOS & $\begin{array}{l}-4.92 \mathrm{E}-05^{*} \\
(-1.67)\end{array}$ & $\begin{array}{l}9.97 \mathrm{E}-03 \\
(0.59)\end{array}$ \\
\hline Slope1 & $\begin{array}{l}-0.11 * * \\
(-2.40) \\
\end{array}$ & $\begin{array}{l}-0.30 * * \\
(-2.54) \\
\end{array}$ \\
\hline Slope2 & $\begin{array}{l}-0.28 \\
(-1.42) \\
\end{array}$ & $\begin{array}{l}-0.09 \\
(-1.23) \\
\end{array}$ \\
\hline R-squared & 0.27 & 0.28 \\
\hline Akaike info criterion & 1.40 & 1.39 \\
\hline Schwarz criterion & 1.53 & 1.53 \\
\hline Durbin-Watson stat & 1.64 & 1.72 \\
\hline
\end{tabular}

In general, the farther from the city center, the lower the land prices [41]. According to Geoghegan [8], this is because towns comprise the main sources of employment, commercial activity, and other urban amenities. It is important to note that the positive sign in the distance variables, does not mean a positive value, but a negative influence on the selling price, since at a shorter distance from that variable, the lower the price of the land. In the present study, it was expected that the MARKET and RURALCOM variables presented a negative sign, but it was the opposite in the case of the double-log model. This may seem a contradiction, however, it could be explained by the importance given by respondents to the presence of urban services near their location, rather than being close to commercial areas, reflecting a lower value for rural areas. 
Hence, it would be expected that the availability and proximity to urban services influence on higher land prices. In this way, the model revealed that the value for urban services is differentiated. For example, the sewage system is the main feature that determines a higher price. For the double-log model, if a plot has sewage, the price increases in $20 \%$. Arguably, respondents might see sewage infrastructure as a more advanced stage in urban development, rising their property's value.

The signs of the coefficients of the distance to highways and roads (VIA and CARR variables), correspond to those found by other authors. For example, Izón et al. [42], reported a coefficient of -0.01 , consistent with our model value of -0.04 and -0.05 . Furthermore, Lara et al. [15], reported that with every $1 \%$ increase in distance to the nearest transport center, the sale price was reduced by $0.15 \%$. It means that the greater the distance with the communication routes, the lower the price of the land. Thus, access to the city is considered very important to people.

Regarding the distance variable to a protected natural area (ANP), it turned out to be negative and significant in both models as expected. Therefore, the value of the property in terms of its proximity to a natural area is positive, but low. Thus, for every $10 \%$ increase in the distance to the protected area, the price will be reduced by $0.35 \%$. This result supports previous studies that have analyzed the influence of a natural area or forest land [42], [43]. To get the elasticities in the semi-log model, the estimated coefficient must be multiplied by the independent variable mean. In this case for every $10 \%$ increase in the distance to a natural protected area, the price will be reduced by $1.8 \%$. The model also shows that land price suffers a 30\% discount if the plot is sloped, as it is inadequate for residential housing. Results are consistent with Abelairas-Etxebarria and Astorkiza [43], who found "reserve effect" on land prices is less powerful than the proximity to the urban area.

In conclusion, the hedonic pricing models presented differentiated value estimates for the sampled plots on sale in the urban fringe of Mexico City. On the one hand, natural areas do have an influence (albeit small) on the selling price. On the other hand, sewage is an important factor in determining the parcel price. This result suggests that individuals value more urban services than open space, and that a parcel not sloped, with sewage system, and access to transportation represents a more valued asset than one located in a rural area. So, this reveals that people who are buying these plots, look presumably for a place to live in close to an urban area, rather than living nearby an environmental asset, because we are facing an informal and irregular land market. Therefore, the information here presented helps to understand the factors of urban growth that can support guiding future public policies. In this sense, to achieve the conservation of this territory, it would be important to focus on stopping investment projects in housing, and to find mechanisms that prevent the sale of plots in the CL of Mexico City.

\section{ACKNOWLEDGEMENT}

This work was supported by the Mexican National Council for Science and Technology (CONACYT) by funding the project 179301 of Basic Science.

\section{REFERENCES}

[1] McMichael, A.J., The urban environment and health in a world of increasing globalization: issues for developing countries. Bulletin of the World Health Organization, 78(9), pp. 1117-1126, 2000.

[2] UNFPA (United Nations Population Fund), State of World Population 2007: Unleashing the Potential of Urban Growth, UNFPA, p. 47, 2007. Online, 
http://www.unfpa.org/publications/state-world-population-2007. Accessed on: 21 Apr. 2016.

[3] Cohen, B., Urbanization in developing countries: Current trends, future projections, and key challenges for sustainability. Technology in Society, 28(1), pp. 63-80, 2006.

[4] Wasson, J. R., McLeod, D.M., Bastian, C.T. \& Rashford, B.S., The effects of environmental amenities on agricultural land values. Land Economics, 89(3), pp. 466478, 2013.

[5] Xu, L., You, H., Li, D. \& Yu, K., Urban green spaces, their spatial pattern, and ecosystem service value: The case of Beijing. Habitat International, 56, pp. 84-95, 2016.

[6] Gómez-Baggethun, E., De Groot, R., Lomas, P.L. \& Montes, C., The history of ecosystem services in economic theory and practice: from early notions to markets and payment schemes. Ecological Economics, 69(6), pp. 1209-1218, 2010.

[7] Pascual, U. et al., The Economics of Valuing Ecosystem Services and Biodiversity. The Economics of Ecosystems and Biodiversity Ecological and Economic Foundations, ed. P. Kumar, Earthscan: London, pp. 183-256, 2010.

[8] Geoghegan, J., The value of open spaces in residential land use. Land Use Policy, 19(1), pp .91-98, 2002.

[9] Almeida-Leñero, L., Nava, M., Ramos, A., Espinosa, M., Ordoñez, M. \& Jujnosky J., Servicios ecosistémicos en la cuenca del río Magdalena, Distrito Federal, México. GacetaEecológica, 84-85, pp. 53-64, 2007.

[10] Martínez-Rivera, E., La Ciudad y el Ambiente como un Solo Sistema: El Suelo de Conservación y su Carácter Estratégico para la Dinámica Urbana del Distrito Federal. $\mathrm{PhD}$ thesis, Mexico, p. 237, 2009 (in Spanish).

[11] Arreguín-Sámano, M. \& Torres-Pérez, J., Modelo de valoración económica del servicio eco sistémico hídrico, delegación La Magdalena Contreras, Distrito Federal. Revista Internacional de Ciencias Sociales y Humanidades, 12(2), pp. 9-23, 2012.

[12] Ibarra, A., Zambrano, L., Valiente, E.L. \& Ramos-Bueno, A., Enhancing the potential value of environmental services in urban wetlands: an agro-ecosystem approach. Cities, 31, pp. 438-443, 2013.

[13] Martínez-Jiménez, E.T., Valoración Económica de los Servicios Ambientales Hidrológicos del Suelo de Conservación del Distrito Federal. Caso de Estudio de la Comunidad de San Miguel y Santo Tomás Ajusco. Master thesis, Mexico, p. 99, 2015. (in Spanish).

[14] Sobrino, J., Housing Prices and submarkets in Mexico City: A hedonic assessment. Estudios Económicos, 29(1), pp. 57-84, 2014.

[15] Lara, J.A., Estrada, G., Zentella, J.C. \& Guevara, A., Los costos de la expansión urbana: aproximación a partir de un modelo de precios hedónicos en la Zona Metropolitana del Valle de México. Estudios Demográficos y Urbanos, 32(1), pp. 3763, 2017.

[16] Chakraborti, L., Heres, D.R. \& Cortés, D.H., Are land values related to ambient air pollution levels? Hedonic evidence from Mexico City, (596), pp. 1-28, 2016.

[17] Freeman III, A.M., Herriges, J.A. \& Kling, C.L., The Measurement of Environmental and Resource Values, Routledge/Resources for the Future Press: New York, 2014.

[18] Rosen, S., Hedonic prices and implicit markets: product differentiation in pure competition. Journal of Political Economy, 82(1), pp. 34-55, 1974.

[19] Bastian, C.T., McLeod, D.M., Germino, M.J., Reiners, W.A. \& Blasko, B.J., Environmental amenities and agricultural land values: a hedonic model using 
geographic information systems data. Ecological Economics, 40(3), pp. 337-349, 2002.

[20] Snyder, S.A., Kilgore, M.A., Hudson, R. \& Donnay, J., Influence of purchaser perceptions and intentions on price for forest land parcels: A hedonic pricing approach. Journal of Forest Economics, 14(1), pp. 47-72, 2008.

[21] Geoghegan, J., Wainger, L.A. \& Bockstael, N.E., Spatial landscape indices in a hedonic framework: an ecological economics analysis using GIS. Ecological Economics, 23(3), pp. 251-264, 1997.

[22] Shonkwiler, J.S. \& Reynolds, J.E., A note on the use of hedonic price models in the analysis of land prices at the urban fringe. Land Economics, 62(1), p. 58, 1986.

[23] Netusil, N.R., The effect of environmental zoning and amenities on property values: Portland, Oregon. Land Economics, 81(2), pp. 227-246, 2005.

[24] Irwin, E.G., Jeanty, P.W. \& Partridge, M.D., Amenity values versus land constraints: The spatial effects of natural landscape features on housing values. Land Economics, 90(1), p. 61, 2014.

[25] Tyrväinen, L., The amenity value of the urban forest: an application of the hedonic pricing method. Landscape and Urban Planning, 37(3), (4), pp .211-222, 1997.

[26] Tyrväinen, L. \& Miettinen, A., Property prices and urban forest amenities. Journal of Environmental Economics and Management, 39(2), pp. 205-223, 2000.

[27] Le Goffe, P., Hedonic pricing of agriculture and forestry externalities. Environmental and Resource Economics, 15, p. 397, 2000.

[28] Cavailhès, J. et al., GIS-based hedonic pricing of landscape. Environmental and Resource economics, 44(4), pp. 571-590, 2009.

[29] Kong, F., Yin, H. \& Nakagoshi, N., Using GIS and landscape metrics in the hedonic price modelling of the amenity value of urban green space: A case study in Jinan City, China. Landscape and Urban Planning, 79(3), pp. 240-252, 2007.

[30] Irwin, E.G. \& Bockstael, N.E., The problem of identifying land use spillovers: measuring the effects of open space on residential property values. American Journal of Agricultural Economics, 83(3), pp. 698-704, 2001.

[31] Instituto Nacional de Estadística y Geografía (INEGI), Censo de Población. INEGI: Mexico, 2010.

[32] Secretaría de Medio Ambiente-Gobierno del Distrito Federal (SEDEMA-GDF), Programa General de Ordenamiento Ecológico Territorial del Distrito Federal 20002003, SEDEMA-GDF: Mexico, 2000.

[33] Sheinbaum, C., La compleja problemática del suelo de conservación del Distrito Federal: apuntes para su conservación. Suelo de Conservación del Distrito Federal: ¿hacia una Gestión y Manejo Sustentables?, eds Pérez-Campuzano, E., Perevochtchikova, M. \& Ávila-Foucat, V.S., Miguel Ángel Porrúa: Mexico, pp. 1338, 2011.

[34] Castelán, J.E. \& Mejía, A., Política ambiental en el Suelo de Conservación del Distrito Federal. Periurbanización y Sustentabilidad en Grandes Ciudades, eds Aguilar, A.G. \& Escamilla, I., Instituto de Geografía-UNAM, CONACYT, Miguel Ángel Porrúa Editor: Mexico, pp. 253-276.

[35] Procuraduría Ambiental y del Ordenamiento Territorial-Secretaría de Medio Ambiente (PAOT-SEDEMA), Atlas Cartográfico del Suelo de Conservación del Distrito Federal. PAOT: Mexico, 2012.

[36] Aguilar A.G \& Santos, C., Asentamientos informales y preservación del medio ambiente Suelo de Conservación del Distrito Federal: ¿hacia una Gestión y Manejo 
Sustentables?, eds Pérez-Campuzano, E., Perevochtchikova, M. \& Ávila-Foucat, V.S., Miguel Ángel Porrúa Editor: Mexico, pp. 93-123, 2011.

[37] Aguilar A.G., Peri-Urbanization, illegal settlements and environmental impact in Mexico City. Cities, 25, pp. 133-145, 2008.

[38] Ford, R.C., Latham, G.P. \& Lennox, G., Mystery shoppers: A new tool for coaching employee performance improvement. Organizational Dynamics, 40(3), pp. 157-164, 2011.

[39] Carr, L. \& Mendelsohn, R., Valuing coral reefs: a travel cost analysis of the Great Barrier Reef. AMBIO: A Journal of the Human Environment, 32(5), pp. 353-357, 2003.

[40] Mashour, T., Alavalapati, J., Matta, R., Larkin, S. \& Carter, D., A hedonic analysis of the effect of natural attributes and deed restrictions on the value of conservation easements. Forest Policy and Economics, 7(5), pp. 771-781, 2005.

[41] Bender, B. \& Hwang, H., Hedonic house price indices and secondary employment centers. Journal of Urban Economics, 17(1), pp. 90-107, 1985.

[42] Izón, G.M., Hand, M.S., Mccollum, D.W., Thacher, J.A. \& Berrens, R.P., Proximity to natural amenities: A seemingly unrelated hedonic regression model with spatial durbin and spatial error processes. Growth and Change, 47(4), pp. 461-480, 2016.

[43] Abelairas-Etxebarria, P. \& Astorkiza, I., Farmland prices and land-use changes in periurban protected natural areas. Land Use Policy, 29(3), pp. 674-683, 2012. 